\title{
シリカライト膜をコートしたムライト質ハニカム多孔体の水熱合成と特性
}

\author{
勝木宏昭·蒲地伸明·杉山 聡*·室永武久* \\ 佐賀県割業技術センター, 844-0024 佐賀県西松浦郡有田町 3037-7 \\ *岩尾磁器工業(株)開発本部, 844-8555 佐賀県西松浦郡有田町 1436-2
}

\section{Hydrothermal Synthesis and Characteristics of Porous Mullite Honeycomb Coated with Silicalite Film}

\author{
Hiroaki KATSUKI, Nobuaki KAMOCHI, Satoru SUGIYAMA* and Takehisa MURONAGA* \\ Saga Ceramics Research Laboratory, 3037-7, Arita-machi, Nishimatsuura-gun, Saga 844-0024 \\ *Technical Department, Iwao Jiki Kogyo Co., Ltd., 1436-2, Arita-machi, Nishimatsuura-gun, Saga 844-8555
}

\begin{abstract}
The formation and some properties of sintered kaolin honeycomb monolith with thick silicalite film, prepared by a hydrothermal reaction, were investigated. To enhance the adhesion strength of the silicalite film onto the honeycomb surface and the mechanical strength of the honeycomb body, the Malaysian kaolin was sintered at $1500^{\circ} \mathrm{C}$ and then treated in $1 \mathrm{M} \mathrm{NaOH}$ solution at $180^{\circ} \mathrm{C}$ to form a partially porous mullite layer on the honeycomb. Silicalite film was hydrothermally prepared on porous honeycomb from colloidal silica, $\mathrm{NaOH}$, tetrapropylammonium bromide and $\mathrm{H}_{2} \mathrm{O}$ at $180^{\circ} \mathrm{C}$. The effect of hydrothermal reaction time on the formation of the silicalite film onto the porous honeycomb surface and Teflon vessel was studied. Due to the formation of a porous mullite layer of 150 to $160 \mu \mathrm{m}$ in thickness on the honeycomb surface by leaching silica in the honeycomb, the adhesion strength of silicalite film on the honeycomb was improved, and a sintered kaolin honeycomb monolith with high strength which was coated with a silicalite film of 100 to $150 \mu \mathrm{m}$ in thickness at $180^{\circ} \mathrm{C}$ for 25 to $30 \mathrm{~h}$ could be prepared by hydrothermal reaction.
\end{abstract}

[Received April 23, 2001; Accepted August 9, 2001$]$

Key-words : Kaolin, Hydrothermal synthesis, Honeycomb, Silicalite film, Porous mullite

\section{1. 緒 言}

ミクロポーラス組織を有する各種ゼオライト材料は，イオン 交換体，吸着材，触媒担体，気体分離材などに利用されてい る1) 77). ゼオライトは非可塑性材料であるのでゼオライト粉末 だけでは押し出成形が困難であり，また自己焼結性がそしいの で $800^{\circ} \mathrm{C}$ 以下では焼結しにくい. $800^{\circ} \mathrm{C}$ 以上の加熱ではミクロ 構造の破壊によるゼオライト固有の特性の劣化が起こりやす い。したがって，ゼオライトを各種形状の触媒担体や吸着材な どに利用する場合には，ゼオライトの可塑性向上のために多量 のバインダーを添加したり，また暁成後の高強度化のために粘 土鉱物，ガラス，無機絨維等が添加されている。しかし，焼成 を700〜800 $\mathrm{C}$ 以下で行う必要があるので高強度を有するハ二 カムやパイプなどのモノリシック体が得られにくい8). 更に Y 型，ZSM-5 型ゼオライトをぜオライトのみからなる膜（自立 膜）として気体分離用の薄膜材料へ利用する場合，ピンホール やマイクロクラックなどの久陷がない連続した維密質のゼオラ イトの自立膜を合成するのが困難であるので, 多孔質のアルミ ナ，ムライト等のパイプやプレートの表面での水熱合成により 作製されている9) 13).

著者らはこれまでにカオリンを焼結して作製した八ニカム体 中に存在するムライトとガラスの $\mathrm{NaOH}$ に対する溶解性の差 を利用した水熱処理により，ムライト質のハ二カム表面に厚さ が50〜 200 $\mu \mathrm{m}$ の ZSM-5 型の緻密なゼオライト膜が生成する ことを報告してきた ${ }^{14) \sim 15)}$ ：この方法では水熱処理条件（温 度, 時間, アルカリ濃度）によりハニカム中のガラスの溶解量 が制御できるので，薄いハニカム壁中に未溶解のガラスを任意 に残存させることができ，屯たハニカム表面は緻密な ZSM-5 膜でコートされるので従来の方法で作製されるハニカムよりも 高強度のハニカム体が得られやすい。しかし，この方法ではム ライトの $\mathrm{Al}$ 成分もわずかにゼオライト骨格中に取り込まれる
ので ZSM-5 中の $\mathrm{SiO}_{2} / \mathrm{Al}_{2} \mathrm{O}_{3}$ (モル比) は25.0〜78.8であり, 高い $\mathrm{SiO}_{2} / \mathrm{Al}_{2} \mathrm{O}_{3}$ 比を持つ ZSM-5 が合成しにくい.したがっ て本研究ではめらかじめハニカム表面部分のガラスを選択的に 溶解させて, 表面が多孔質のムライトハニカムを作製した. ゼ オライトのシリカ源としてコロイダルシリカを用い, 表面が部 分的に多孔質化されたハニカム上への高シリカ質 ZSM-5 型ゼ オライトであるシリカライト膜の水熱合成とその特性を検討し た.

\section{2. 実験方法}

2.1 多孔質ムライトハニカム体の合成

原料にはマレーシアカオリンを用い, 前報と同様の方法で一 辺の長さが $18 \times 18 \mathrm{~mm}$, セルサイズが $1.5 \times 1.5 \mathrm{~mm}$, 壁厚さが $500 \mu \mathrm{m}$ の八二カムを押し出成形により作製した15). 乾燥後 $350^{\circ} \mathrm{C}$ で脱バインダー処理し $1500^{\circ} \mathrm{C} て ゙ 2 \mathrm{~h}$ 焼成した。この焼結 八ニカム中には長さが $2 \sim 5 \mu \mathrm{m}$ で太さが $1 \mu \mathrm{m}$ 以下の柱状あ るいは針状のムライトが59〜62 mass \%, シリカが $38 \sim 41$ mass\%生成していた ${ }^{15)}$ ４ムライトとシリカの $\mathrm{NaOH}$ 水溶液に 対する溶解性の差を利用して焼結八二力ム表面のみを部分的に 多孔質化するため, 焼結八二力ムを $180^{\circ} \mathrm{C} の 1 \mathrm{M} \mathrm{NaOH}$ 水溶液 中で $1 \sim 14 \mathrm{~h}$ 処理した. 多孔質化の程度を八二力么断面の走査 型電子顕微鏡（SEM；日本電子製，840型）観察と水銀ポロシ メーター測定（Micrometrics 製, Autopore III-9420型）によ る細孔径分布, 気孔率測定より評価した。

\section{2 八二カム上でのシリカライトの水熱合成と特性}

表面を部分的に多孔質化した八二カム上でのシリカライト膜 の合成には，原料としてコロイダルシリカ（日産化学，ス） ティック $\mathrm{N}, \mathrm{SiO}_{2}$ 含有量 $20.4 \%$ ), 臭化テトラプロピルアンモ 二ウム $(\mathrm{TPABr}$, 和光純薬工業製), $\mathrm{NaOH}$ (和光純薬工業製) 及び純水を用いた。シリカライト膜を合成するため, Sano 
ら 16), Tsikoyiannis ら ${ }^{17)} の$ 万法を応用した。原料の組成がモル 比で $\mathrm{SiO}_{2}$ : TPABr : NaOH : $\mathrm{H}_{2} \mathrm{O}=100: 12: 9: 5710$ になる ように混合し, 室温で $24 \mathrm{~h}$ かくはんして透明なり゙ル溶液を作 製した．2.1節で作製した多孔質八二カムとこのゾルをステン レス製の耐圧容器で保護された $50 \mathrm{ml}$ のテフロンセルに入れ, $180^{\circ} \mathrm{C} て ゙ 2 \mathrm{~h}$ か $548 \mathrm{~h}$ の水熱処理によりハニカム上でのシリ力 ライトの合成を行った．な拈各実験ではハニカムを同じサイズ （約 $3.3 \mathrm{~g} ）$ に切断し, 原料溶液は $40 \mathrm{ml}$ とした. またハニカム と反応溶液を均一に接触させるために八二力ムをセル内に白金 線でつるして反応を行った，水熱処理後，八二力ムを洗浄一乾 燥し， $600^{\circ} \mathrm{C} て ゙ 12 \mathrm{~h}$ 酸化処理してシリカライト中に含有されて いる錆型剤の TPABr を除去した。原料ゾル中のシリカのシリ カライトへの転換率をハニカム上，テフロン内壁上に分けて評 価した.シリカライトの生成形態及び特性評価を XRD（RADB 型, 理学製), SEM, 及び $\mathrm{N}_{2}$ ガスによる比表面積測定（湯 浅アイオニクス製, Autosorb 1) で行った. シリカライト膜で 被覆されたハニカム, テフロン容器に析出したシリカライト膜 を分別一洗浄し，それぞれ $250^{\circ} \mathrm{C} て ゙ 18 \mathrm{~h}$ 脱気してから比表面積 測定を行った。なお，シリカライト膜で被覆されたハニカムの 比表面積は膜をハ二カムから分離せずそのまま測定した．更 に, シリカを溶出したハ二カムとシリカライトをコートした八 ニカムの圧縮強度を前報 ${ }^{14)}$ と同様にして評価した。

\section{3. 結果と考察}

\section{1 多孔質ムライトハニカムの特性}

まず $1500^{\circ} \mathrm{C} て ゙$ 焼成したハニカムの表面のみを多孔質化する ために, $180^{\circ} \mathrm{C}$ の $1 \mathrm{M} \mathrm{NaOH}$ 水溶液中に抢けるシリカの溶出を 検討した.八二カムの重量減少は 4, 8, 13, $16 \mathrm{~h}$ の处理で10.5, $19.6,34.5,43.2$ mass\%であった. 図 1 には $4,13 \mathrm{~h}$ 処理後のハ ニカムの断面組織を示すが, 約 $4 \mathrm{~h}$ の処理でシリカの溶出が明 嘹に認められハ二力ム表面は深さ約 $80 \mu \mathrm{m}$ までが多孔質化され た. $16 \mathrm{~h}$ の処理でほぼ八二カム中のシリカは溶出し, 図 1(c) のようなムライト結晶のみからなる多孔体となった．水銀ポロ シメーター測定によるこの多孔質層の平均気孔直径は $0.28 \mu \mathrm{m}$

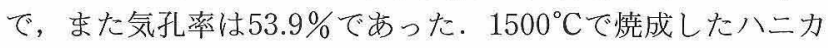

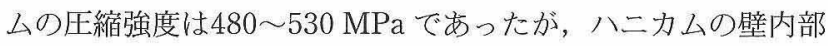
から溶出するシリカ量とともに开縮強度は低下し， $8 \mathrm{~h}$ 及び $13 \mathrm{~h}$ の溶出処理で八二カムの圧縮強度は328 342 MPa 及び 343〜358 MPa となった．八ニ力ム中のシリ力を完全に溶出す るとムライトのみから構成される多孔質の八二カムが生成する が，圧縮強度は30〜 $50 \mathrm{MPa}$ まで低下した，以上のようにハニ 力ム表面層のみを部分的に微細なムライト結晶だけで多孔質化 させ，八ニカム内部に高強度のシリカとムライトの緻密混合層 を多く残存させることにより，高圧縮強度の八二カム体が作製 できることが分かった。

\section{2 シリカライトの生成と特性}

焼結体中のシリカを $1 \mathrm{M} \mathrm{NaOH}$ 水溶液中で $180^{\circ} \mathrm{C}, 8 \mathrm{~h}$ の処理 により溶出させ，八二カム表面に厚さが $150 \sim 160 \mu \mathrm{m}$ の多孔 質ムライト層を生成させたハニカム上でのシリカライトの水熱 合成を検討した．まず図 2,3 には $180^{\circ} \mathrm{C} て ゙ ~ 8,24 \mathrm{~h}$ 反応後の八 二力ムのXRD 図と八二カムの断面と表面の組織を示すが, $8 \mathrm{~h}$ の反応でシリカライト $\left(\mathrm{SiO}_{2} \cdot 9.5 \mathrm{H}_{2} \mathrm{O}\right.$, JCPDS file no. 44-696) の回折パターンを示す結晶が多孔質ムライトの表面に緻密に生 成した．八二カムの断面と表面の SEM 観察から，このシリカ ライト結晶はサイズが20〜 $50 \mu \mathrm{m}$ のブロック状めるいはサイ コロ状結晶であり，八ニカム表面に対して配向せず結晶の詰ま り方も粗いことが分かった.しかし図 3(b)より多孔質ムライ
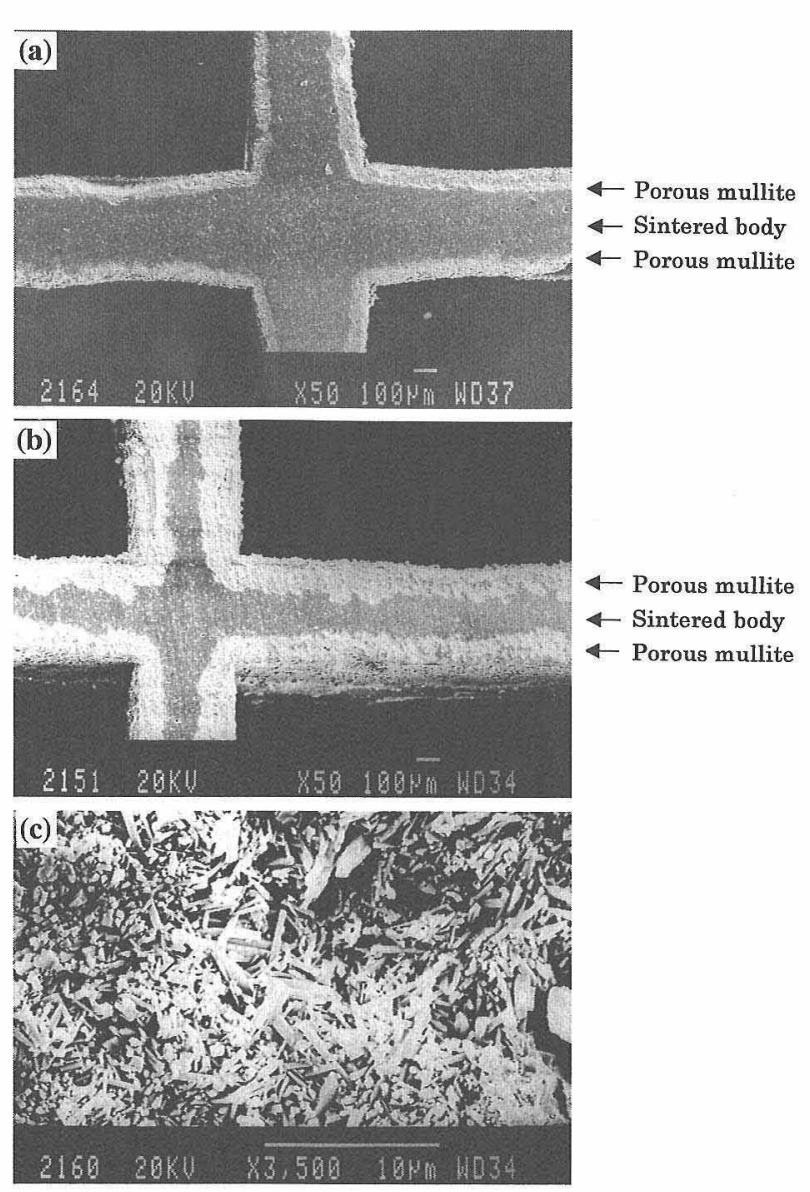

Fig. 1. Morphologies of polished surfaces of the sintered Malaysia kaolin honeycomb prepared by leaching silica with $1 \mathrm{M} \mathrm{NaOH}$ solution at $180^{\circ} \mathrm{C}$ for (a) 4 , (b) $13 \mathrm{~h}$ and (c) $16 \mathrm{~h}$. In (c), mullite crystals are observed.

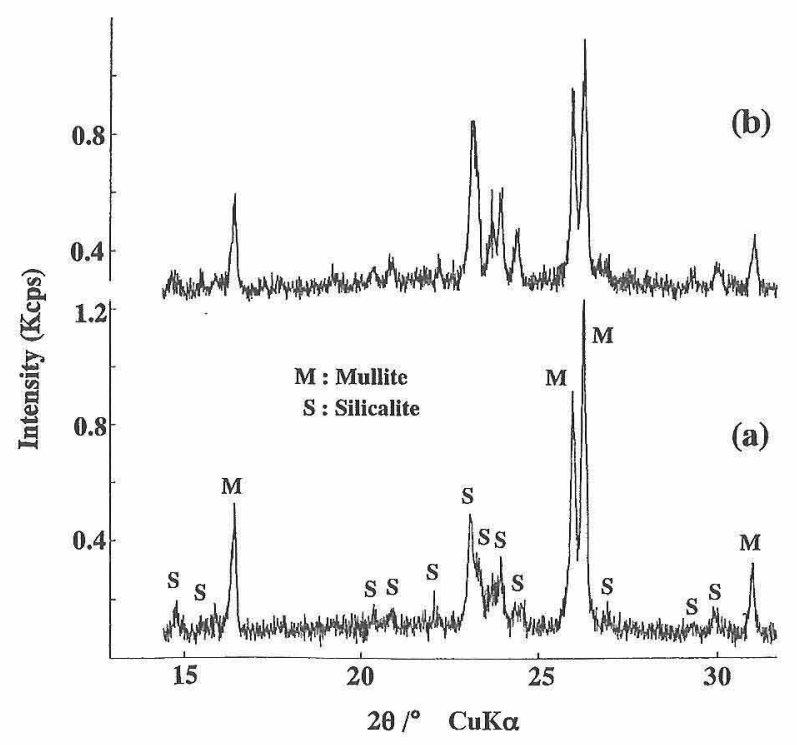

Fig. 2. XRD patterns of sintered kaolin honeycombs coated with silicalite films by a hydrothermal reaction from colloidal silica, $\mathrm{NaOH}, \mathrm{TPABr}$, and $\mathrm{H}_{2} \mathrm{O}$ at $180^{\circ} \mathrm{C}$ for (a) $8 \mathrm{~h}$ and (b) $24 \mathrm{~h}$.

ト層とシリカライト層の界面には厚さが 10～20 $\mu \mathrm{m}$ の混合層 が生成し, 多孔質のムライト層中にシリカライトが混在していた. 

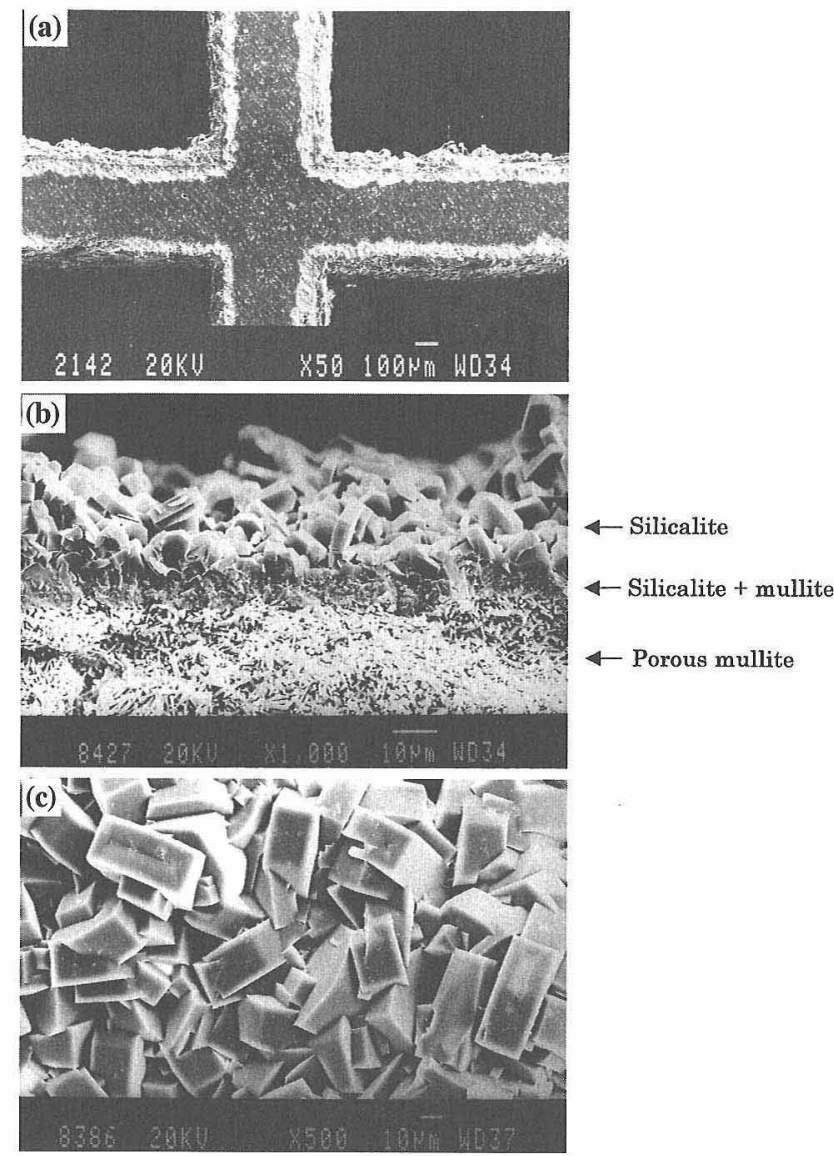

Fig. 3. Morphologies of silicalite films formed on the honeycomb by a hydrothermal reaction at $180^{\circ} \mathrm{C}$ for $8 \mathrm{~h}$. (a), (b): polished surfaces of the honeycomb, (c): surface of silicalite films deposited on the honeycomb.

シリカライトは高温で負の熱膨張係数を示し，テンプレート として結晶内に取り込まれた $\mathrm{TPABr}$ がなくなる500 $\mathrm{C}$ 付近で は基板とシリカライトとの間に大きな熱膨張係数の差が生じ, 機械的強度の低いシリカライト層に大きな歪みがかかるのでピ ンホールやマイクロクラックができやすいことが水上により指 摘されている18)，比較のために $1500^{\circ} \mathrm{C} て ゙$ 暁成したままのハ二
カム上に $180^{\circ} \mathrm{C}-30 \mathrm{~h}$ の水熱処理により，厚さが $130 \sim 150 \mu \mathrm{m}$ のシリカライト膜を析出させた．しかし $600^{\circ} \mathrm{C}$ の酸化処理によ りシリカライト膜内にマイクロクラックが生じ，また焼結した ままのハニカムの表面は平滑であるのでシリカライト膜が厚く なるほどはく離しやすくなった。一方，八ニカムの表面をシリ 力の選択的溶解で多孔質化してからシリカライト膜を析出させ ると，柱状あるいは針状のムライト結晶がアンカー効果として シリカライト膜を強く固着するので $600^{\circ} \mathrm{C}-12 \mathrm{~h}$ のテンプレー 卜除去処理後もシリカライト膜はハニカムからはく離しなかっ た.

つぎにハニカム上とテフロン内壁上でのシリカライトの生成 量からコロイダルシリカのシリカライトへの転換率を調べた。

表 1 Kコロイダルシリカのシリカライトへの転換率のほかに生 成するシリカライト膜の厚さに及ぼす水熱処理時間の影響を示 す，八二カム上，テフロン内壁上では水熱処理時間の増大とと もにシリカライトの生成は増加し, $30 \mathrm{~h}$ 以降では八二カム上 及びテフロン内壁上では転換率がそれでれ40～45, 53〜 55\%に なりコロイダルシリカ中のシリカ成分はほぼシリカライトに転 換した．ところで水熱処理中に八二カム及びテフロンセルが原 料溶液に接触する外部表面積はそれぞれ78, $52 \mathrm{~cm}^{2}$ であった。 シリカライトの生成が両者の表面で均一に起こると仮定すれば 八ニ力ムの外部表面積の力が大きいので，八二カム上でのシリ カライトへの転換率が大であることが推定される。しかし，水 熱処理時間が長くなるほど八二カム表面上でのシリカライトと の生成はテフロン内壁上のそれよりも8～15\%低下した。 た，八ニカムのセル内壁上で生成したシリカライトの膜厚は 30〜 35 h 以降む 130〜 $160 \mu \mathrm{m}$ であり，顕著に増加しなかっ た.これは水熱処理時間とともに溶液中のシリカ濃度が次第に 低下すること，更には八二カムの個々のセルサイズが $1.4 \times 1.4$ $\mathrm{mm}$ と狭く, セル中での原料溶液の移動が起こりにくいので水 熱処理時間が長くなるとセル内壁表面でのシリカライトの析出 が㧩制されたものと推察しているが，他の多くの要因も考えら れ現段階ではその理由は明確でない，

表 2 にシリカライト膜をコートしたハニカムの比表面積と圧 縮強度の結果を示ず.シリカライトの生成には焼結体中のシリ 力を $1 \mathrm{M} \mathrm{NaOH}$ 水溶液中で $180^{\circ} \mathrm{C}, 8 \mathrm{~h}$ の処理により部分的に溶 出させたハこカムを用いた。 圧縮強度はシリカライト膜の厚さ が増加しても380〜 400 MPa であり，八二カム上に析出した緻 密なシリカライト膜の補強効果は認められなかった。シリカを

Table 1. Effect of Hydrothermal Reaction Time on the Formation of Silicalite Films on the Honeycomb and Tefelon Vessel at $180^{\circ} \mathrm{C}$

\begin{tabular}{cccc}
\hline \multirow{2}{*}{$\begin{array}{l}\text { Reaction } \\
\text { time (h) }\end{array}$} & \multicolumn{2}{c}{$\begin{array}{c}\text { Conversion of colloidal silica to silicalite } \\
\text { on honeycomb (\%) }\end{array}$} & $\begin{array}{c}\text { Thickness of silicalite } \\
\text { on teflon vessel }(\%)\end{array}$ \\
\hline 2 & 0.6 & 5.5 & - \\
4 & 3.4 & 9.0 & $<10$ \\
8 & 11.2 & 15.4 & $40-70$ \\
14 & 19.3 & 27.1 & $80-100$ \\
18 & 23.5 & 36.5 & $90-120$ \\
24 & 32.6 & 43.4 & $110-130$ \\
30 & 39.8 & 54.1 & $130-150$ \\
35 & 42.1 & 55.0 & $130-160$ \\
48 & 45.0 & 53.4 & $140-150$ \\
\hline
\end{tabular}


Table 2. BET Surface Areas and Fractured Compressive Strength of the Honeycomb with Silicalite Film Hydrothermally Prepared at $180^{\circ} \mathrm{C}$

\begin{tabular}{ccc}
\hline Reaction time (h) & Surface area $\left(\mathrm{m}^{2} / \mathrm{g}\right)$ & Strength (MPa) \\
\hline 0 & 4.6 & $354-375$ \\
8 & 37.7 & $336-351$ \\
14 & 49.8 & $322-365$ \\
24 & 73.6 & $341-356$ \\
30 & 78.4 & $330-344$ \\
\hline
\end{tabular}

部分的に溶出したハニカム内壁中には厚さが約 $300 \mu \mathrm{m}$ の未溶 解のシリカとムライト層が残存していた. 一般的にゼオライト は脆く, 本研究でテフロン内壁に析出した厚さが約 $250 \mu \mathrm{m}$ の シリカライト膜も簡単に破壊されやすい. 八二カム中の未溶解 層の方がシリカライト膜よりもはるかに高強度であるために, 補強効果が認められなかったものと考えられる。一方 $180^{\circ} \mathrm{C} の$ $1 \mathrm{M} \mathrm{NaOH}$ 水溶液中で $8 \mathrm{~h}$ シリカを部分的に溶出したハニカム の比表面積は $4.6 \mathrm{~m}^{2} / \mathrm{g}$ であったが，八ニカムの比表面積はシ リカライトの生成とともに増加し, $30 \mathrm{~h}$ の水熱処理で膜厚が 130 150 $\mu \mathrm{m}$ のシリカライトをコートしたハニカムの比表面 積は $78.4 \mathrm{~m}^{2} / \mathrm{g}$ となった. なおテフロン内壁に析出したシリカ ライト膜の比表面積は $283 \mathrm{~m}^{2} / \mathrm{g}$ であった。

\section{4. 結言}

ゼオライト膜の機械的強度を改善するために, 本研究ではシ リカライト膜でコートされたムライト質のハニカムモノリシス の水熱合成とその特性を検討した。 まずハニカム表面へのシリ カライト膜の密着強度とハ二カム体の機械的強度の向上のため に，マレーシアカオリンハニカムを $1500^{\circ} \mathrm{C}$ で焼成後, $180^{\circ} \mathrm{C}$ の $1 \mathrm{M} \mathrm{NaOH}$ 水溶液中でシリカを選択的に溶解することにより, ハニカムの表面部分に多孔質のムライト層を生成させた。この ように処理したハニカムをコロイダルシリカ, $\mathrm{TPABr}, \mathrm{NaOH}$ と $\mathrm{H}_{2} \mathrm{O}$ の混合溶液に浸し $180^{\circ} \mathrm{C}$ で水熱処理することにより部 分的に表面を多孔質化したハニカム上にシリカライト膜を生成 させることができた．八ニカム表面に厚さが $150 〜 160 \mu \mathrm{m}$ の 多孔質のムライト層を生成させるとシリカライトが多孔質層に 取り达まれ, 混合層ができるのでシリカライト膜の密着性が改 善され, $600^{\circ} \mathrm{C} て ゙ の$ 熱処理後もシリカライト膜はハニカム表面 からはく離しなかった. またハニカム中に未溶解のシリカとム ライト層を残存させることによりハニカムの強度を維持するこ とができた. $180^{\circ} \mathrm{C} て ゙ 14 〜 30 \mathrm{~h}$ の水熱処理により, 厚さが $80 \sim$ $150 \mu \mathrm{m}$ のシリカライト膜でコートされた高強度のムライト質 のハニカムモノリシスが生成することが分かった。
謝辞 本研究の一部は科学技術振興事業団が佐賀県, 佐賀 県地域産業支援センターと実施中の地域研究開発促進拠点支援事 業の中で, 平成 12 年度可能性試験の一部として行われたものであ る.ここに記して謝意とする。

\section{文献}

1) Hamada, H., Kintachi, Y., Sasaki, M., Ito, T. and Tabata, M., Appl. Catal., 64, L1-4 (1990).

2) Iwamoto, M. and Hamada, H., Catal. Today, 10, 57-71 (1991).

3) Keil, F. J., Hindere, J. and Garayhi, A. R., Catal. Today, 50, 637-50 (1995).

4) Antina, J. E. and Covind, R., Ind. Eng. Chem. Res., 34, 140-47 (1995).

5) Shu, J., Adont, A. and Grandjean, B. P. A., Ind. Eng. Chem. Res., 38, 3860-67 (1999).

6) Takeuchi, Y., Zeolite News Lett., 17, 61-66 (2000) [in Japanese].

7) Choi, E. Y., Kim, Y. and Seff, K., Microporous and Mesoporous Mater., 41, 61-68 (2000).

8) Takeuchi, T. and Mouri, M., Zeolite News Lett., 11, 121-30 (1994) [in Japanese].

9) Geus, E. R., Exter, M. J. and Bekkum, H., J. Chem. Soc., Faraday Trans., 88, 3101-09 (1992).

10) Yan, Y., Tsapatsis, M., Gavalas, G. R. and Davis, M. E., J. Chem. Soc., Chem. Commun., 1995, 227-28 (1995).

11) Kita, H., Horita, T., Asanuma, H., Tanaka, K. and Okamoto, K., Proc. 5th Int. Conf. Inorg. Membranes, Nagoya (1998) p. 210 , p. 536.

12) Kusakabe, K., Kuroda, T. and Morooka, S., J. Membrane Sci., 148, 13-23 (1998)

13) Kondo, M., Komori, M., Kita, H. and Okamoto, K., J. Membrane Sci., 133, 133-41 (1997).

14) Katsuki, H., Furuta, S. and Komarneni, S., J. Am. Ceram. Soc., 83, 1093-97 (2000).

15) Katsuki, H., Kamochi, N. and Komarneni, S., J. Ceram. Soc. Japan, 109, 33-38 (2001).

16) Sano, T., Yanagishita, H., Kiyozumi, Y. and Mizukami, F., J. Membrane Sci., 95, 221-28 (1994).

17) Tsikoyiannis J. G. and Haag, W. O., Zeolites, 12, 126-30 (1992).

18) Mizukami, F., J. Surfa. Sci. Soc. Japan, 19, 36-42 (1998). 